\title{
Cycad seed dispersal - the importance of large frugivorous birds
}

Author(s):

Symes CT
Journal editor:

Pete Laver

Manuscript editor:

Pete Laver

Received: January 25, 2018; Accepted: July 6, 2018; Published: July 6, 2018

\section{Citation: Symes CT. 2018. Cycad seed dispersal - the importance of large frugivorous birds. Biodiversity Observations 9.4:1-9}

Journal: https:/ /journals.uct.ac.za/index.php/BO/

Manuscript: https://journals.uct.ac.za/index.php/BO/article/view/503

PDF: https://journals.uct.ac.za/index.php/BO/article/view/503/546

HTML: http:/ / thebdi.org/blog/2018/07/06/cycad-seed-dispersal
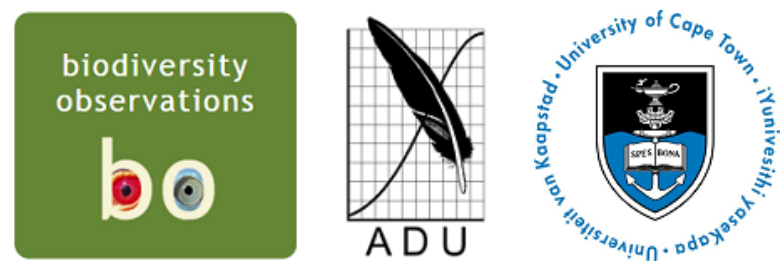

Biodiversity Observations is an open access electronic journal published by the Animal Demography

Unit at the University of Cape Town, available at https://journals.uct.ac.za/index.php/BO/

The scope of Biodiversity Observations includes papers describing observations about biodiversity in general, including animals, plants, algae and fungi. This includes observations of behaviour, breeding and flowering patterns, distributions and range extensions, foraging, food, movement, measurements, habitat and colouration/plumage variations. Biotic interactions such as pollination, fruit dispersal, herbivory and predation fall within the scope, as well as the use of indigenous and exotic species by humans. Observations of naturalised plants and animals will also be considered. Biodiversity Observations will also publish a variety of other interesting or relevant biodiversity material: reports of projects and conferences, annotated checklists for a site or region, specialist bibliographies, book reviews and any other appropriate material. Further details and guidelines to authors are on the journal website (https://journals.uct.ac.za/index.php/BO/). 


\title{
Cycad seed dispersal - the importance of large frugivorous birds
}

\author{
Craig T. Symes School of Animal, Plant and Environmental Sciences, University of the Witwatersrand, \\ Private Bag 3, Wits 2050, South Africa, craig.symes@wits.ac.za
}

Cycads are of conservation importance yet very little research has been done on the dispersal of their fruit, particularly in Africa (Dyer 1965; Howe 1986; Murray 1986). Indeed, in an attempt to read up on the topic I discovered that many of the published accounts are secondary, anecdotal, and descriptive. In this paper I report on some of these reports, as well as new records (pers. obs.; various pers. comm. - see acknowledgements). I furthermore highlight the role that large frugivorous birds play in the dispersal of large seeds like cycads.

At a site near Nelspruit $\left(25^{\circ} 34^{\prime} \mathrm{S}, 31^{\circ} 11^{\prime} \mathrm{E}\right.$, altitude $=800 \mathrm{~m}$ a.s.l.), Mpumalanga Province, I monitored a fruiting Encephalartos villosus (family Zamiaceae) using two motion-sensitive camera traps (Bushnell). The cameras, mounted on tripods at a height of about 1 metre, were erected at c. 07h00 on 30 October 2011 and removed the following day at c. 09h00. They were set at high sensitivity to take three images with an interval between triggering of 15 seconds. The cycad plant was growing in a savanna thicket, with two other smaller cycad plants, and quite inconspicuous in the thick vegetation. The most commonly recorded species observed visiting the fruiting plant was Purple-crested Turaco Gallirex porphyreolophus (Figure 1).

In one image a bird can be seen with an entire fruit in the bill and it is not unreasonable to assume that they swallowed fruit whole (Figure 1). By combining the sequence of visitation events using the photographs I was able to deduce that two visits $(<2$ minutes each, one in the morning and one in the afternoon) were made by a single bird on 30 October 2011, and on 31 October 2011 three visits ( $<2$ minutes each) were made by a single bird, and one further visit by two birds (c. 4 minutes). The visits can be summarized as follows:

\section{- 30 October 2011}

- 08:36:15 - single turaco arrives at plant, with images of the bird climbing on branches around the cone and on the ground nearby; departs c. 08:38:24.

- 13:22:14 - a single baboon walks between the camera and the cycad.

- 15:17:34 - a single Dark-capped Bulbul Pycnonotus tricolor arrives on the cone, at 15:19:27 two birds appear to be feeding on fruit.

- 18:08:56 - single turaco arrives at plant, with images of the bird climbing on branches around the cone; flies off 18:10:29.

\section{- 31 October 2011}

- 06:56:58 - single turaco observed on plant near cone; departs c. 06:58:12.

- 06:58:27 - single turaco observed perched next to cones, fruit observed in bill, departs c. 06:59:36.

\footnotetext{
Biodiversity Observations is an open access electronic journal published by the Animal Demography Unit at the University of Cape Town, available at https://journals.uct.ac.za/index.php/BO/. A permanent link for an online version of this manuscript can be found at https://journals.uct.ac.za/index.php/BO/article/view/503, which includes the PDF: https://journals.uct.ac.za/index.php/BO/article/view/503/546. An HTML version can be found at http:/ / thebdi.org/blog/2018/07/06/cycad-seed-dispersal.

Journal editor: Pete Laver; Manuscript editor: Pete Laver; Corresponding author: craig.symes@wits.ac.za

Received: January 25, 2018; Accepted: July 6, 2018; Published: July 6, 2018

Recommended citation: Symes CT. 2018. Cycad seed dispersal - the importance of large frugivorous birds. Biodiversity Observations 9.4:1-9

Manuscript subject: Avian diet
} 

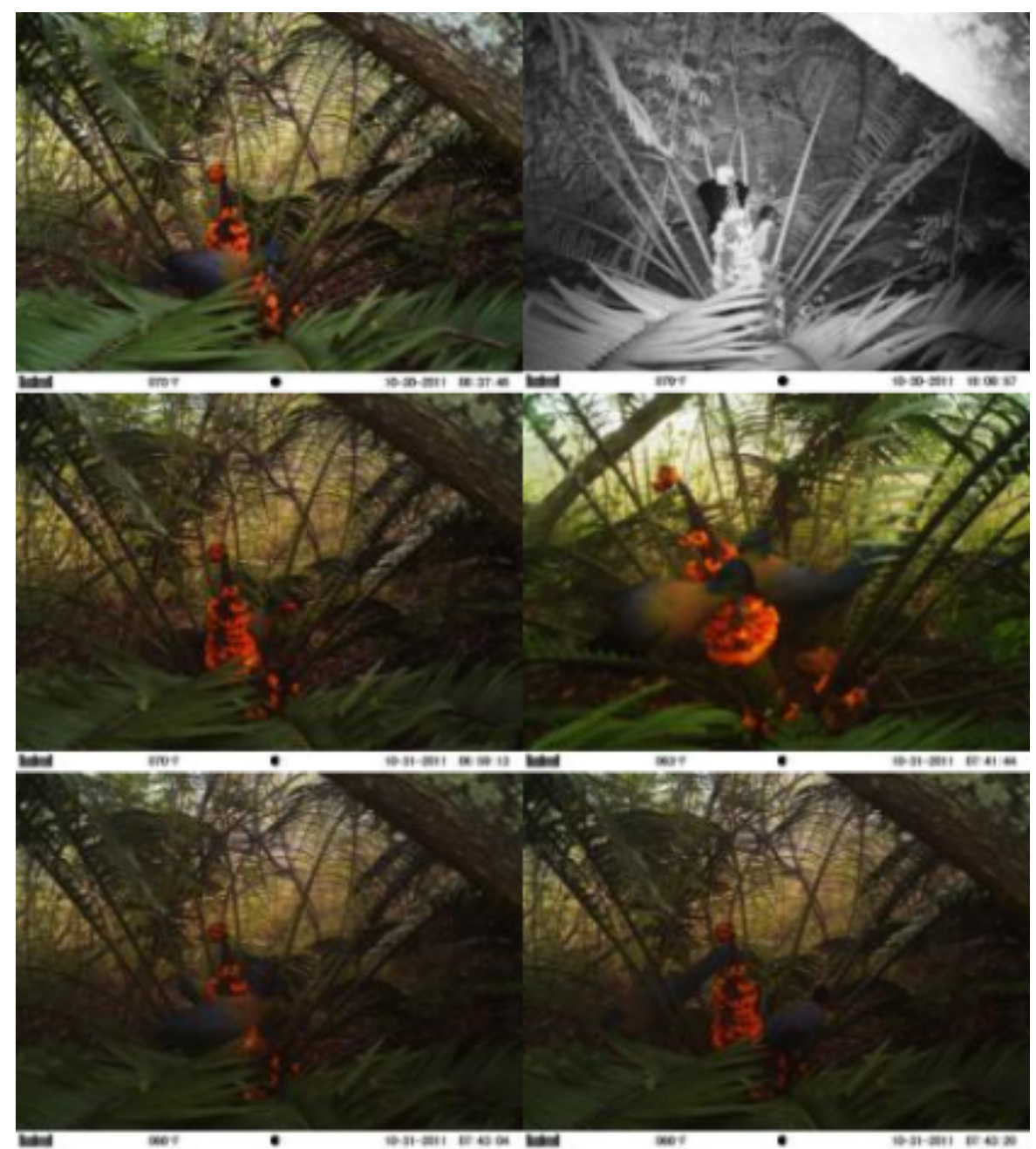

Figure 1: Camera trap photographs of Purple-crested Turaco Gallirex porphyreolophus visiting Encephalartos villosus to feed on fruit, Nelspruit, October 2011 (Photos: Craig Symes). 
- 07:39:39 - single turaco on ground next to cycad, joined by second bird at 07:41:44, only one turaco on cycad at 07:42:05, two birds again observed at 07:43:04, these two depart at c. 07:44:02 and c. 07:44:40, respectively.

- 08:41:26 - single turaco observed feeding on fruit, departs c. 08:42:39.

The most likely attractant for the birds is the starchy sarcotesta, a bright red fleshy covering to the seeds. This activity was similarly recorded by Warwick Tarboton, who recorded a Purple-crested Turaco feeding on the fruit of Encephalartos villosus (likely species) in Ithala Game Reserve, KwaZulu-Natal, in September 2016 (Figure 2). Geoff Nichols has also recorded Knysna Turaco Tauraco corythaix swallowing whole fruit of E. villosus at Southport, KwaZuluNatal South Coast (Geoff Nichols pers. comm.). Nearby at Oribi Gorge main camp (14-15 October 2010), I similarly photographed, using camera traps, Knysna Turacos visiting a fruiting cycad (possibly E. villosus), where the turacos were clearly seen eating the red cycad fruits. Furthermore, an early account (Jubb 1964, 1965) notes a Knysna Turaco feeding on the fruit of E. altensteinii and subsequently regurgitating the seed.

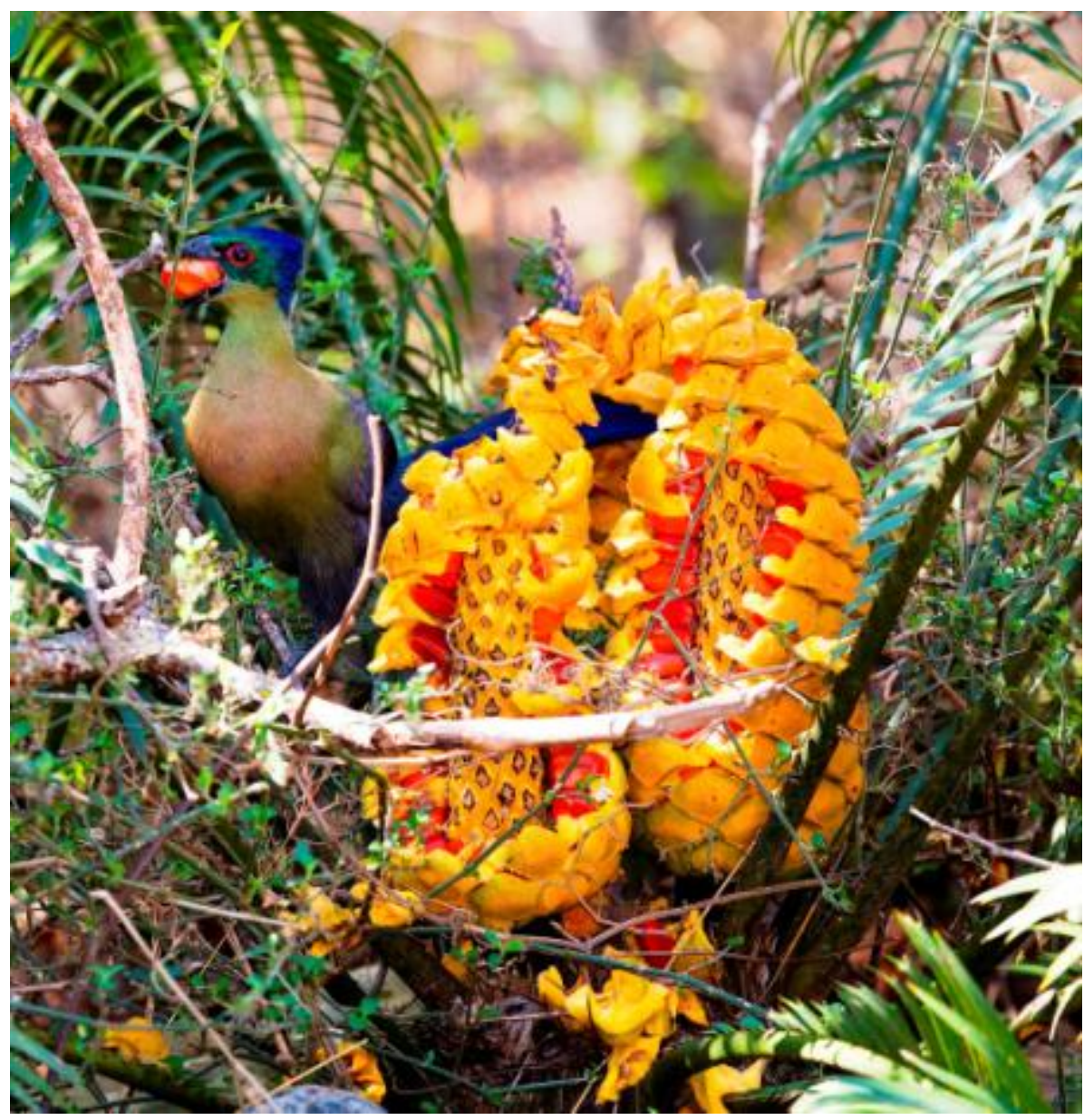

Figure 2: Purple-crested Turaco Gallirex porphyreolophus feeding on fruit of Encephalartos villosus (likely species) at Ithala Game Reserve, KZN in Sept 2016. (Photo: Warwick Tarboton).

At the Nelspruit site, discarded fruit found beneath the fruit cone showed evidence of feeding by other animals, probably smaller birds or small mammals that are unable to swallow the fruit whole (Figure 3) and Dark-capped Bulbuls were also photographed at the fruiting cycads (Figure 4). Other birds may also be attracted to the bright red fruits and the following observations have been made; Sombre Greenbul Andropadus importunus and Yellow-rumped Tinkerbird Pogoniulus bilineatus feeding on E. senticosus fruit (Geoff Nichols pers. comm.; Figure 4); 
and Yellow Weaver Ploceus subaureus on E. lebomboensis at Mtunzini (Hugh Chittenden pers. comm.; Figure 4). Also, an Olive Thrush Turdus olivaceus was observed feeding two chicks the cycad seed flesh (sarcotesta) at Kleinemonde in October 2004 (Williams 2005), and a Crested Barbet Trachyphonus vaillantii feeding "the soft flesh around the seed of a cycad to nestlings" (Hattingh 2012). Skead (1997) records a number of species feeding on the cycad species E. altensteinii, including Black-collared Barbet Lybius torquatus, Crowned Hornbill Tockus alboterminatus, Dark-capped Bulbul, European Starling Sturnus vulgaris, Amethyst Sunbird Chalcomitra amethystina (details of this record and what this species may have been feeding on are unclear) House Sparrow Passer domesticus, and Streaky-headed Seedeater Serinus gularis.

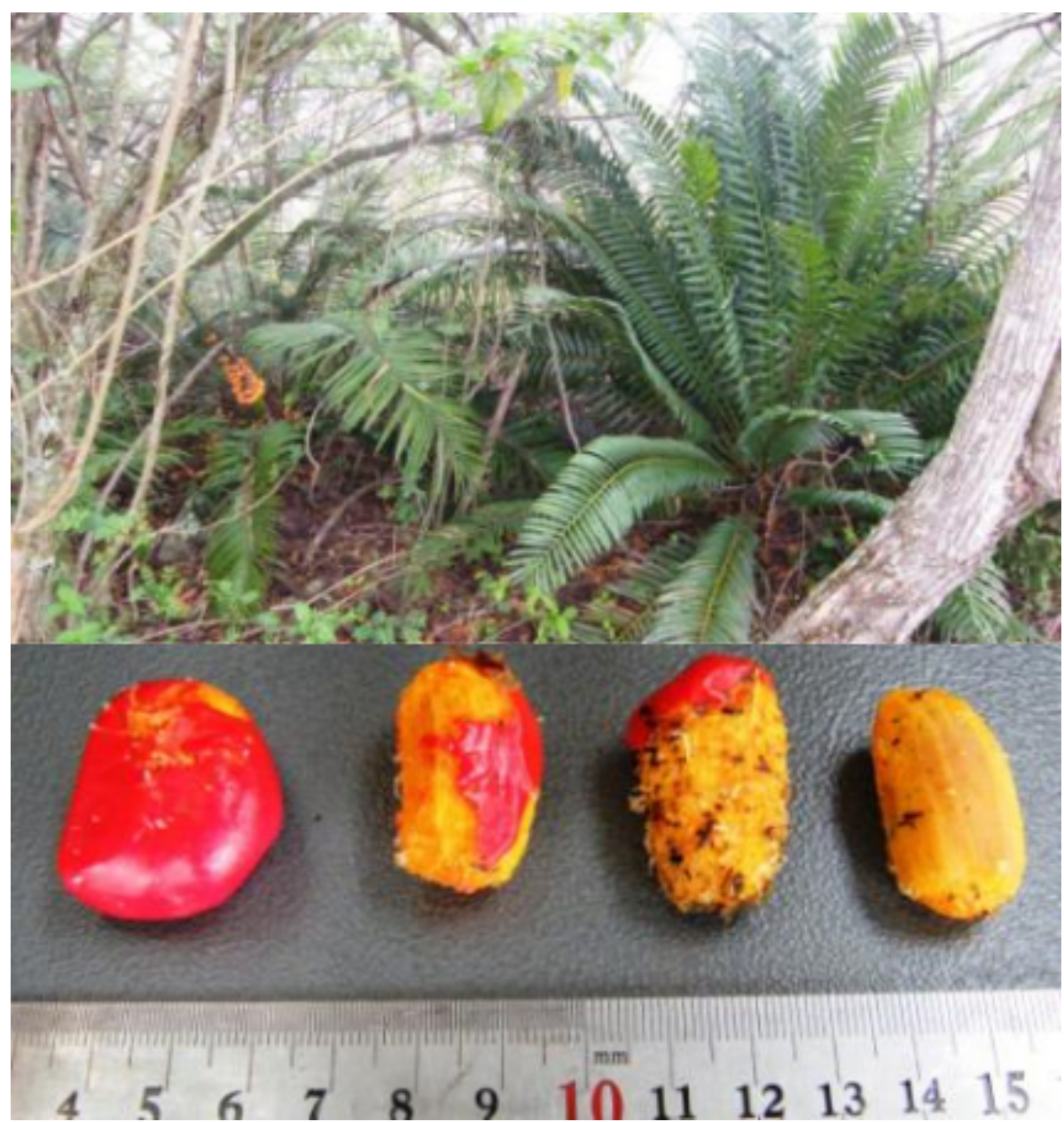

Figure 3: Encephalartos villosus plants at which Purple-crested Turaco Gallirex porphyreolophus were observed feeding, and fruit showing evidence of feeding (probably by smaller birds or small mammals that are unable to swallow fruit whole), 31 October 2011 (numbers indicate centimetres on rule; Photos: Craig Symes).

Large frugivores may be important long-distance seed dispersers for cycads. Crowned Hornbill, Trumpeter Hornbill Bycanistes bucinator, and Cape Parrot Poicephalus robustus suahelicus are known to feed on cycad seeds (Grobbelaar 2004). In a recent review of cycads (Cousins and Witkowski 2017) these authors report that these species "carry cycad seeds over long distances to their nests where they consume the sarcotesta and drop the intact kernel (Grobbelaar 2004)." The statement that these birds carry cycad seeds to their nests is somewhat perplexing, especially for the Cape Parrot. While I have observed Greyheaded Parrot Poicephalus fuscicollis suahelicus flying with the fruit of five different species (including Mobola Plum Parinari curatel- 


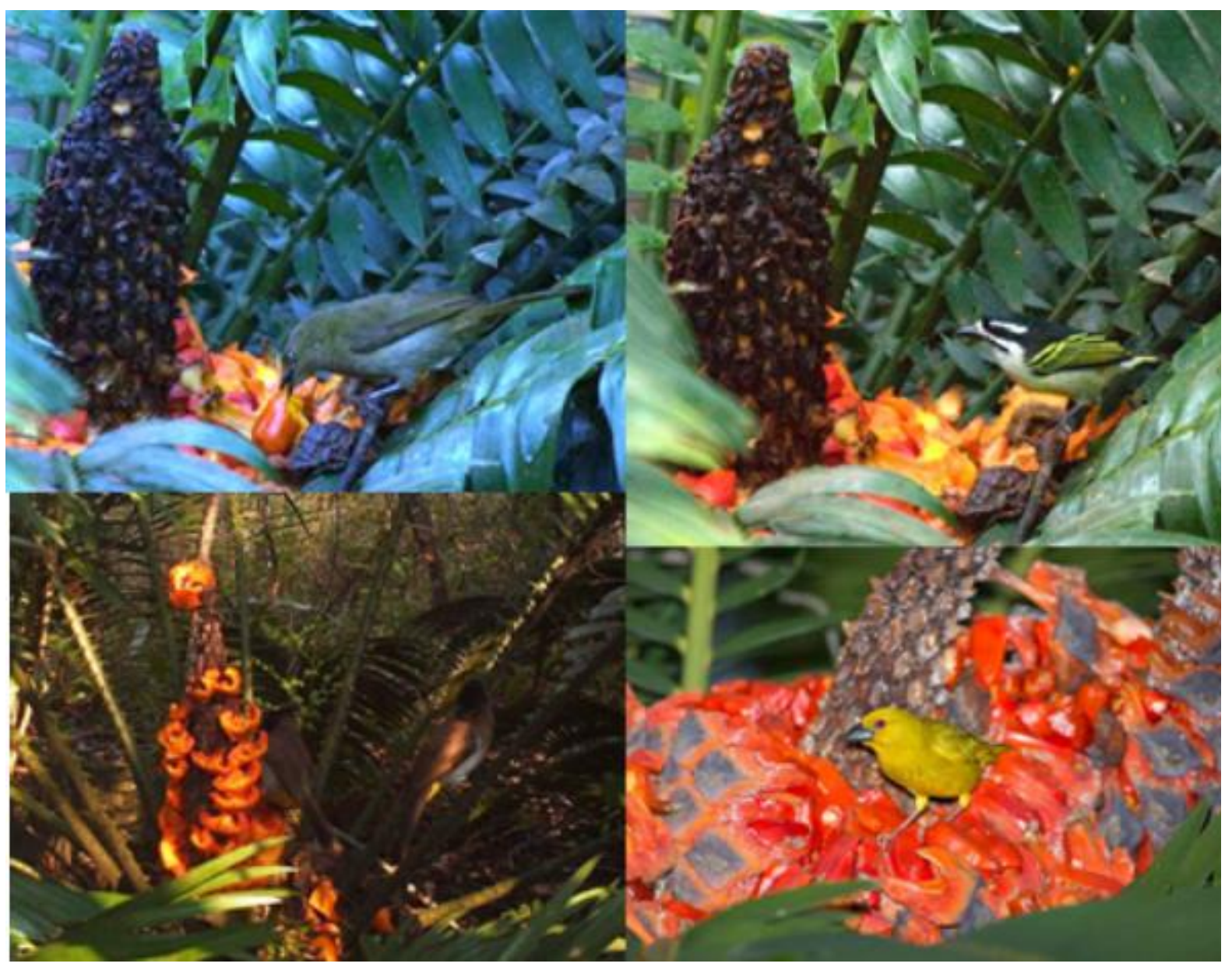

Figure 4: From left to right and top to bottom: Sombre Greenbul Andropadus importunus and Yellow-rumped Tinkerbird Pogoniulus bilineatus feeding on Encephalartos senticosus fruit at Southport, KwaZulu-Natal South Coast (Photos: Geoff Nichols), Dark-capped Bulbul Pycnonotus tricolor feeding on Encephalartos villosus near Nelspruit, Mpumalanga (Photo: Craig Symes), and Yellow Weaver Ploceus subaureus on Encephalartos lebomboensis at Mtunzini, KwaZulu-Natal (Photo: Hugh Chittenden). 
lifolia) (Symes and Perrin 2003), I have not observed the same with Cape Parrot Poicephalus robustus, nor have I seen either species returning to the nest-cavity with fruit during breeding (Wirminghaus et al 2001; Symes and Perrin 2004). In these two parrot species food is regurgitated for the female (by the male) while she is incubating, and by both sexes for the nestlings (Wirminghaus et al 2001; Symes and Perrin 2004). However, this behaviour is not unlikely for hornbills because the two indicated species, Crowned Hornbill and Trumpeter Hornbill, are widely recorded to feed on cycad fruit (Kemp 2005). Trumpeter Hornbill has been reported feeding on E. villosus at Southport, KwaZulu-Natal South Coast (Geoff Nichols pers. comm.), and Crowned Hornbill has been observed feeding on E. ferox at Kosi Bay and Lake Sibaya (Geoff Nichols pers. obs.), and returning cycad fruit to a nest in Eshowe, KwaZulu-Natal (likely species E. lebomboensis; Hugh Chittenden pers. comm.; Figure 5). These latter observations support early accounts of regular feeding on cycad fruit by Crowned Hornbill in the Eastern Cape, and of returning fruit to the nest (Ranger 1950). Bill Howells (pers. comm.) has similarly reported Crowned Hornbill foraging on E. ferox fruit at a colony of c. 250 plants near Kosi Bay, KwaZulu-Natal north coast, and Ingrid Weiersbye (pers. comm.) has observed the same interaction at St. Lucia slightly further south. Fescura (2014) also reported a family group of Crowned Hornbill consuming "cycad seeds with great gusto", swallowing the whole fruit (location not given).

Purple-crested Turaco (family Musophagidae) is almost entirely frugivorous, feeding on a wide selection of fruit that are usually swallowed whole (du Plessis and Dean 2005). Turacos are restricted to Africa and constitute an ancient lineage of Gondwana origin (Tuinen and Valentine 1986). The bird-fruit association may be a long one (Mustoe 2007) especially considering that cycads (Order Cycales) are an ancient plant group with over 300 extant species today. They have probably remained functionally unchanged since the Jurassic, and in that time constituted an important component of the diet of ancestral "turacos". However, while the lineage is ancient it is estimated that most extant cycad species have evolved in the past 12 million years (Nagalingum et al. 2011).

While there are numerous accounts of cycad fruit forming an important component of the diet (despite evidence that cycads can be toxic, Tustin 1983, Schneider et al. 2002) of many other animals (Cousins and Witkowski 2017), including Chacma Baboon Papio hamadryas, Vervet Monkey Cercopithecus pygerythrus, African Elephant Loxodonta africana, Bush Pig Potamochoerus larvatus, Rock Hyrax Procavia capensis, and rodents (e.g. vlei rats Otomys spp.) (Melville 1957; Giddy 1984; Grobbelaar 2004; Donaldson 2008), it is more likely, because of their ability to move greater distances over a shorter period of time, that birds are more efficient seed dispersers (Burbidge and Whelan 1982; Tang 1989; Mueller et al. 2014; Baños-Villalba et al. 2017). Their role as important seed dispersers for effective ecosystem functioning, and the maintenance of interactions that contributes to the dispersal of cycads, a plant group of major conservation importance, certainly warrants further research. 


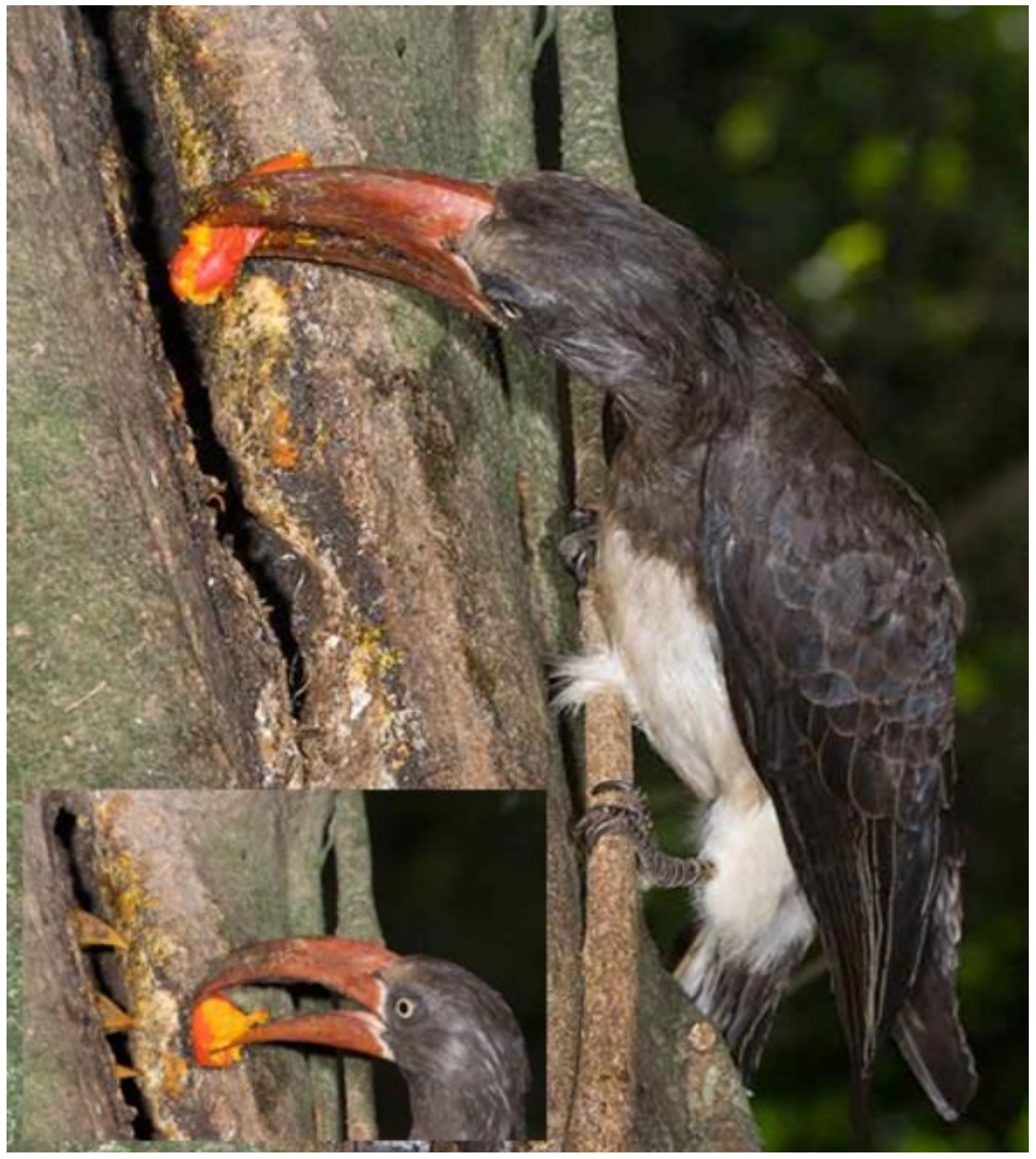

Figure 5: Crowned Hornbill returning cycad fruit to a nest in Eshowe (likely species Encephalartos lebomboensis; Photo: Hugh Chittenden). 


\section{Acknowledgements}

De Wet Bösenberg, Hugh Chittenden, Stephen Cousins, Greg Davies, John Donaldson, Bill Howells, Geoff Nichols, Darren Pietersen, Warwick Tarboton, Ingrid Weiersbye, and Vivienne Williams are thanked for their respective contributions to assisting in the preparation of this paper.

\section{References}

Baños-Villalba A, Blanco G, Díaz-Luque JA, Dénes FV, Hiraldo F, Tella JL 2017. Seed dispersal by macaws shapes the landscape of an Amazonian ecosystem. Scientific Reports 7: 7373.

Burbidge AH, Whelan RJ 1982. Seed dispersal in a cycad, Macrozamia riedlei. Austral Ecology 7: 63-67.

Cousins S, Witkowski E 2017. African cycad ecology, ethnobotany and conservation: A synthesis. The Botanical Review 83: 152-194.

Donaldson JS 2008. South African Encephalartos species. NDF workshop case studies: Case study 4: Encephalartos. Mexico.

Du Plessis MA, Dean WRL 2005. Purple-crested Turaco Gallirex porphyreolopus. In: Hockey P, Dean R, Ryan P (eds) Roberts' birds of southern Africa, 7th edition. John Voelcker Bird Book Fund. Cape Town: 248-249.

Dyer RA 1965. The cycads of southern Africa. Bothalia 8: 405-515.

Fescura L 2014. Chair's Chirps - Birdlife Port Natal. KZN Birds 41: 3-6.

Giddy C 1984. Cycads of South Africa. 2nd edition. C. Struik (Pty) Ltd. Publishers, Cape Town.

Grobbelaar N 2004. Cycads: With special reference to the southern African species. Published by the author. Pretoria.

Hattingh K 2012. Crested Barbets nesting in our garden. Laniarius 122: 35-37.

Howe HF 1986. Seed dispersal by fruit-eating birds and mammals. In: Murray DR (ed) Seed Dispersal Academic Press: Sydney: 123-189.

Jubb RA 1964. A Christmas visitor. Bokmakierie 16(1): 8-9.

Jubb RA 1965. Knysna Loerie Turacus corythaix (Wagler) feeding on poisonous plants. Ostrich 36(1): 36-37.

Kemp AC 2005. Crowned Hornbill Tockus alboterminatus. In: Hockey P, Dean R, Ryan P (eds) Roberts' birds of southern Africa, 7th edition. John Voelcker Bird Book Fund. Cape Town: 153-154.

Melville R 1957. Encephalartos in central Africa. Kew Bulletin 12: 237-257.

Mueller T, Lenz J, Caprano T, Fiedler W, Böhning-Gaese K 2014. Large frugivorous birds facilitate functional connectivity of fragmented landscapes. Journal of Applied Ecology 51(3): 684-692. 
Mustoe GE 2007. Coevolution of cycads and dinosaurs. Cycad Newsletter 30:6-9.

Nagalingum NS, Marshall CR, Quental TB, Rai HS, Little DP, Mathews S 2011. Recent synchronous radiation of a living fossil. Science 334(6057): 796-799.

Murray DR (ed) 1986. Seed dispersal. Academic Press: Sydney.

Ranger G 1950. Life of the crowned Hornbill (Part III). Ostrich 21: 2-14.

Schneider D, Wink M, Sporer F, Lounibos P 2002. Cycads: their evolution, toxins, herbivores and insect pollinators. Naturwissenschaften 89: 281-294.

Skead C 1995. Life history notes on East Cape bird species (1940-1990) Vol 1. Algoa Regional Services Council, Port Elizabeth.

Skead C 1997. Life history notes on East Cape bird species (1940-1990) Vol 2. Bird biology and bird movement in the Eastern Cape. Western District Regional Services Council (Formerly Algoa Regional Services Council), Port Elizabeth.

Symes CT, Perrin MR 2003. Feeding biology of the Greyheaded Parrot, Poicephalus fuscicollis suahelicus (Reichenow), in Northern Province, South Africa. Emu 103: 49-58.

Symes CT, Perrin MR 2004. Breeding biology of the Greyheaded Parrot (Poicephalus fuscicollis suahelicus) in the wild. Emu 104: 45-57.

Tang W 1989. Seed dispersal in the cycad Zamia pumila in Florida. Canadian Journal of Botany 67: 2066-2070.

Tuinen P, Valentine M 1986. Phylogenetic relationships of turacos (Musophagidae; Cuculiformes) based on comparative chromosome banding analysis. Ibis 128: 364-381.

Tustin R 1983. Notes on the toxicity and carcinogenicity of some South African cycad species with special reference to that of Encephalartos lanatus. Journal of the South African Veterinary Association 54: 33-42.

Williams A 2005. Observations - breeding. Diaz Diary 33(1): 20.

Wirminghaus JO, Downs CT, Perrin MR, Symes CT 2001. Breeding biology of the Cape Parrot, Poicephalus robustus. Ostrich 72: 159-164. 